\title{
Opettajien ammatillinen identiteetti, toimijuus ja sitoutuminen
}

\author{
väljä- ja tiukkakytkentäisessä koulutusorganisaatiossa
}

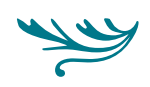

Tämän päivän opettajat elävät toiminta- ja hallintokulttuurin murroksessa.

Erityisesti opettajantyön hallinnollinen säätely ja ulkoinen kontrollointi näyttävät lisääntyvän. Tällaisessa tilanteessa on ajankohtaista kysyä, miten opettajat kokevat koulutusorganisaatioidensa hallintokulttuurit ja niiden muutokset sekä millainen on niiden merkitys heidän ammatillisuudelleen ja työlleen.

PUREUDUMME TÄSSÄ ARTIKKELISSA erityisesti siihen, miten kaksi eri tavoin hallinnoitua koulutusorganisaatiota luovat rajoitteita ja mahdollisuuksia opettajien ammatillisille orientaatioille, toimijuudelle ja organisaatioon sitoutumiselle. Lisäksi pohdimme, miten koulutusorganisaatioita tulisi johtaa, jotta ne olisivat opettajille mielekkäitä työympäristöjä ja jotta ne samanaikaisesti mahdollistaisivat tarpeelliset muutokset koulutuksessa ja organisaation toiminnassa.

Opettajilla on perinteisesti ollut runsaasti vapautta vaikuttaa työnsä sisältöön ja omiin työtapoihinsa. He ovat pystyneet vapaasti toteuttamaan ammatillisia tavoitteitaan ja orientaatioitaan, kun heidän työhönsä ei ole kohdistunut vahvaa hallinnollista säätelyä. On myös ajateltu, että opettajien ammatillista kehittymistä voidaan parhaiten tukea, kun koulutusorganisaatioiden johtamisessa korostetaan opettajien mahdollisuutta päätöksentekoon ja heidän toimintavapauttaan (Hargreaves 2000). Koulutusorganisaatioita, jotka toimivat näin, voidaan kuvata väljäkytkentäisiksi organisaatioiksi (Meyer 2002; Weick 1976). Väljäkytkentäisissä organisaatioissa yksilöt, yhteisöt ja toiminnot ovat toisiinsa väljästi sidoksissa ja näiden vuorovaikutus on suunnittelematonta. Väljäkytkentäisten organisaatioiden hallinnossa korostuu matala hierarkia sekä heikko ulkoinen kontrolli opettajien työhön ja opettajien työtä koskevaan päätöksentekoon. Yksilöillä on myös mahdollisuus vastustaa muutoksia, mistä johtuen muutokset tällaisissa organisaatioissa ovat maltillisia ja hitaita. (Meyer \& Rowan 1977; Weick 1976; ks. myös Vanhalakka-Ruoho 2006.)

Viime vuosina monissa koulutusorganisaatioissa on siirrytty noudattamaan yrityselämästä omaksuttua uuden julkisjohtamisen (new public management) mallia (Helgøy, Homme \& Gewirtz 2007; Rinne 2003). Koulutusorganisaatioille uuden julkisjohtamisen periaatteet ja niiden täytäntöönpano on merkinnyt uudenlaisen toimintalogiikan omaksumista. Nykyään koulutusorganisaatioiden arkea ovat laatu-, tuloksellisuus- ja tehokkuuskriteerit sekä 
jatkuva arviointi. Koulutusorganisaatioissa tapahtuneita muutoksia voidaan kuvata myös siirtymänä väljäkytkentäisistä kohti tiukkakytkentäisiä koulutusorganisaatioita. Tiukkakytkentäisissä organisaatioissa painotetaan vahvaa ja strategista johtamista tähdäten tehokkuuteen ja tuloksellisuuteen. (Meyer 2002; Moos 2005; ks. myös Vanhalakka-Ruoho 2006.) Tämä on johtanut siihen, että opettajien työtä kontrolloidaan yhä enemmän hallinnollisilla määräyksillä ja heidän ammatilliset vaikutusmahdollisuutensa työn sisältöjen ja päämäärien neuvottelussa kaventuvat.

Tiukkakytkentäisissä organisaatioissa yksittäiset toimijat ja yhteisöt työskentelevät tiiviisti yhdessä ja ovat aiempaa vahvemmin linkittyneitä eri toimintatasoihin ja hallintoon. Kun koulutusorganisaatioissa pyritään tehostamaan toimintaa, opettajat kohtaavat jatkuvia ja ulkoapäin ohjattuja muutosvaatimuksia (Meyer 2002; Moos 2005). Vahvan sosiaalisen kontrollin ja säätelyn oletetaan myös tukevan opettajien ammatillista kehittymistä sekä organisaatioiden uudistumista. Koulutusorganisaatiot voidaan erotella niiden hallinnollisten ja toiminnallisten pääpiirteiden perusteella edellä kuvatusti joko väljä- tai tiukkakytkentäisiksi. Tällainen jako ei ole kuitenkaan absoluuttinen, sillä organisaatioissa on usein piirteitä molemmista hallintotavoista (Weick 2001).

Tässä artikkelissa tarkastelemme opettajien työtä ja ammatillisia identiteettineuvotteluja kahdessa eri tavoin hallinnoidussa koulutusorganisaatiossa, ammatillisessa oppilaitoksessa ja opettajankoulutuslaitoksessa. Tarkastelemme ammatillisia identiteettineuvotteluja erityisesti siitä näkökulmasta, kuinka erilaiset organisaatiot luovat rajoitteita ja mahdollisuuksia opettajien ammatillisten orientaatioiden harjoittamiselle, toimijuudelle ja organisaatioon sitoutumiselle.

\section{AMMATILLISET IDENTITEETTINEUVOTTELUT, TOIMIJUUS JA SITOUTUMINEN}

Ammatillinen identiteetti määritellään yksilön käsitykseksi itsestään ammatillisena toimijana. Se sisältää yksilön työtä koskevat arvot, mielenkiinnon kohteet, tavoitteet, uskomukset ja näkemykset siitä, mihin hän kokee kuuluvansa ja samaistuvansa (Beijaard, Meijer
\& Verloop 2004; Day, Elliot \& Kington 2005; Little \& Bartlett 2002). Opettajien ammatilliseen identiteettiin kuuluvat myös opetusta ja oppimista koskevat käsitykset. Tässä artikkelissa tarkastelemme opettajien ammatillisia orientaatioita osana heidän ammatillista identiteettiään (esimerkiksi van Veen, Sleegers, Bergen \& Klaassen 2001). Orientaatio määritellään opettajan näkemykseksi siitä, mikä hänelle on työssä tärkeintä, sekä näkemykseksi tehtävistä, jotka opettaja kokee merkityksellisiksi itselleen.

Tutkimuksemme pohjautuu teoreettisesti subjektikeskeiseen sosiokulttuuriseen lähestymistapaan (esimerkiksi Eteläpelto 2008). Sosiokulttuurinen lähestymistapa (van Huizen, van Oers \& Wubbels 2005; Lasky 2005) painottaa erityisesti sosiaalisen kontekstin ja sosiaalisten suhteiden merkitystä kaikessa inhimillisessä toiminnassa. Tämä tarkoittaa sitä, että ammatillisten yhteisöjen ja organisaatioiden sosiaaliset käytänteet, sosiokulttuuriset ja taloudelliset resurssit, arvot ja normit luovat resursseja yksilöiden toiminnalle ja identiteettineuvotteluille. Sosiokulttuurisessa lähestymistavassa ei kuitenkaan ole riittävästi korostettu yksilön aktiivisuutta ja yksilöllisten tekijöiden merkitystä, minkä vuoksi hyödynnämme lisäksi teorioita, jotka painottavat subjektin aktiivista roolia ja toimijuutta työssä (esimerkiksi Fenwick 2006).

Toimijuus ymmärretään mahdollisuudeksi tehdä ammatillisia, omaan työhön liittyviä valintoja ja päätöksiä niin, että ne perustuvat myös yksilön ammatillisiin kiinnostuksen kohteisiin ja tavoitteisiin. Yksilö kykenee toimimaan myös yksilöllisistä lähtökohdistaan eikä hänen identiteettinsä ja toimintansa ole pelkästään ympäristön sanelemaa (Eteläpelto \& Saarinen 2006; Fenwick 2006). Toimijuuden harjoittamisen ymmärrämme merkitsevän myös sitä, että opettajat pystyvät neuvottelemaan aktiivisesti oman työnsä ehdoista ja sisällöistä sekä vaikuttamaan työyhteisöönsä ja organisaatioonsa. Tämä sisältää esimerkiksi mahdollisuuden neuvotella hallinnosta tulevista ohjeistuksista ja tarvittaessa vastustaa niitä.

Kaiken kaikkiaan subjektikeskeinen sosiokulttuurinen lähestymistapa mahdollistaa opettajien työn ja identiteettineuvottelujen tarkastelun siten, että otetaan huomioon opettajien yksilölliset lähtökohdat ja 
taustat sekä työpaikan sosiokulttuurinen konteksti. Erilaisten työympäristöjen hallinnollisine säätelyineen voidaan olettaa luovan vaihtelevasti tilaa opettajien toiminnalle ja ammatillisten orientaatioiden harjoittamiselle (vrt. Billett 2007). Keskustelemme koulutusorganisaation sosiokulttuurisen kontekstin ja opettajien ammatillisten identiteettineuvottelujen välisestä suhteesta pääosin sitoutumisen näkökulmasta (Baruch \& Cohen 2007).

\section{TUTKIMUKSEN TAVOITTEET}

Tutkimuksen tavoitteena on ymmärtää opettajien ammatillisia identiteettineuvotteluja tarkastelemalla ja vertailemalla kahta hallinnolliselta säätelyltään erilaista koulutusorganisaatiota. Tutkimuskysymykset ovat seuraavat:

1. Kuinka opettajat kuvaavat koulutusorganisaationsa hallinnollista säätelyä työorganisaation, ammatillisen lähiyhteisön ja yksilön tasolla?

2. Kuinka opettajat kuvaavat ammatillista orientaatiotaan?

3. Millainen on opettajien erilaisten ammatillisten orientaatioiden ja koulutusorganisaatioissa esiintyvän hallinnollisen säätelyn suhde?

\section{TUTKIMUKSEN TOTEUTUS}

\section{Aineiston hankinta ja osallistujat}

Haastattelimme tutkimukseemme 24 opettajaa, jotka työskentelivät ammatillisessa toisen asteen oppilaitoksessa ja yliopiston opettajankoulutuslaitoksessa. Opettajat olivat eri-ikäisiä ja opettivat eri aineita. Lisäksi he olivat työskennelleet organisaatiossaan vaihtelevan ajan. Aineisto kerättiin avoimilla narratiivisilla haastatteluilla 2005-2006. Haastatteluissa käsiteltiin muun muassa opettajan työn luonnetta, ammatillista kehittymistä, työorganisaatiota ja ammatillista yhteisöä sekä työhön liittyviä tulevaisuuden odotuksia. Haastattelut nauhoitettiin ja litteroitiin analyysiä varten.

\section{Aineiston analyysi}

Aineiston analyysissä sovelsimme laadullista sisällönanalyysiä ja teemoittelua (Braun \& Clarke 2006; Patton 2002). Analyysissa keskityimme opettajien yksilöllisiin näkemyksiin ja kokemuksiin, mutta tavoitteenamme oli löytää yleisimpiä kuvauksia aineiston pohjalta. Analysoimme aineiston tutkimuskysymysten mukaisesti.

Ensimmäisessä analyysivaiheessa luimme läpi kaikki haastattelut tunnistaaksemme, kuinka opettajat kuvaavat koulutusorganisaatioitaan yleisellä tasolla. Holistisen luennan avulla havaitsimme, että eri organisaatioiden opettajat kuvaavat organisaatioitaan eri tavoin.

Erityisesti tarkastelemiemme organisaatioiden toiminta- ja johtamistavoissa vaikuttaa olevan eroja. Ammatillisessa oppilaitoksessa opettajat kuvaavat työtään tiukasti ulkoapäin ohjatuksi ja hallinnoiduksi. Yliopiston opettajankoulutuslaitoksessa opettajat taas kuvaavat työn ulkoisen kontrollin vähäiseksi. Opettajien haastattelujen analysoinnin perusteella erotimmekin kaksi erilaista kuvaustapaa organisaatioiden toiminta- ja hallintokulttuureille. Nimetessämme näitä kahta erilaista kuvaustapaa hyödynsimme erityisesti Meyerin (2002) ja Weickin (1976) käyttämiä käsitteitä tiukka- ja väljäkytkentäinen organisaatio. Opettajien kuvausten perusteella nimesimme ammatillisen oppilaitoksen tiukkakytkentäiseksi ja yliopiston opettajankoulutuslaitoksen väljäkytkentäiseksi organisaatioksi.

Luimme haastattelut uudelleen ja vertailimme opettajien kuvauksia tarkentaaksemme organisaatioiden välisiä yhtäläisyyksiä ja eroja. Tematisoimalla pystyimme määrittelemään ne piirteet ja ominaisuudet, jotka osoittavat yksityiskohtaisesti erot ja yhtäläisyydet koulutusorganisaatioiden välillä. Koulutusorganisaatioiden väliset erot ja yhtäläisyydet ryhmittelimme työorganisaation, ammatillisen lähiyhteisön ja yksilön tasolle.

Toisessa analyysivaiheessa analysoimme ja tulkitsimme sitä, mitä opettajat sanovat pitävänsä työssä tärkeimpänä sekä mitä työtehtäviä he kertovat pitävänsä merkityksellisinä. Kuvauksista erottelimme ja teemoittelimme neljä sisällöllisesti toisistaan eroavaa ammatillista orientaatiota. Lopuksi analysoimme opettajien kertomien kokemusten ja kuvausten pohjalta sitä, mikä on opettajien ammatillisten orientaatioiden suhde koulutusorganisaation hallinnolliseen säätelyyn. Tällä tavoin selvitimme, kuinka opettajat 
kokevat voivansa harjoittaa ammatillisia orientaatioitaan eri tavoin hallinnoiduissa koulutusorganisaatioissa.

Tutkimuksemme rajoitteena voi nähdä sen, että tutkimusaineistona hyödynsimme ainoastaan opettajien haastatteluja eri organisaatioista. Kun organisaatioiden kuvaukset pohjautuvat opettajien yksilöllisiin näkemyksiin ja kokemuksiin, ne eivät välttämättä kuvaa organisaatioiden todellisia olosuhteita ja toimintatapoja. Toinen rajoite tutkimuksessamme liittyy käyttämiimme väljä- ja tiukkakytkentäisyyden käsitteisiin, joita hyödynsimme koulutusorganisaatioiden nimeämisessä. Nämä käsitteet ovat selitysvoimaisia kuvaamaan organisaatioiden erilaisia tapoja säädellä hallinnollisesti opettajien työtä. Tutkimuksessamme ne eivät ole kuitenkaan yhtä päteviä kuvaamaan yksittäisten opettajien ja ammattiryhmien välisten kytkösten ja sidoksien voimakkuutta.

Seuraavissa luvuissa esittelemme tulokset tutkimuskysymysten mukaan.

\section{OPETTAJIEN KUVAUKSET HALLINNOLLISESTA}

\section{SÄÄTELYSTÄ}

Hallinnollinen säätely erosi vahvuudeltaan tutkimissamme koulutusorganisaatioissa. Taulukossa 1 esitämme työorganisaatiotason, ammatillisen lähiyhteisötason sekä yksilötason hallinnollista säätelyä. Ammatillisen lähiyhteisön ymmärrämme koostuvan opettajista, jotka opettavat samaa oppiainetta.

\section{Tiukkakytkentäisen organisaation hallinnollinen säätely}

Työorganisaatiotaso. Haastattelemamme opettajat kertoivat kohdanneensa viime vuosina jatkuvia, laajoja ja päällekkäisiä muutoksia organisaatiossaan. Oppilaitoksen organisaatiorakenne ja hallintokulttuuri ovat muuttuneet merkittävästi. Lisäksi valtakunnalliset ja oppilaitoskohtaiset uudistukset määrittelevät uudelleen koulutuksen sisältöjä ja toteutusta. Uudistukset ovat myös tuoneet mukanaan uusia ja laajentuneita työtehtäviä opettajille. Opettajat totesivat, että uudistusten

TAULUKKO 1. Opettajien kuvaukset

koulutusorganisaatioista

työorganisaatiotasolla, ammatillisella

lähiyhteisötasolla ja yksilötasolla

\begin{tabular}{|c|c|c|}
\hline & $\begin{array}{l}\text { TIUKKAKYTKENTÄINEN } \\
\text { ORGANISAATIO }\end{array}$ & $\begin{array}{c}\text { VÄLJÄKYTKENTÄINEN } \\
\text { ORGANISAATIO }\end{array}$ \\
\hline \multicolumn{3}{|c|}{ TYÖORGANISAATIOTASO } \\
\hline Organisaatiokulttuuri & jatkuvat muutokset & vakaus \\
\hline Johtaminen & hierarkia & matala hierarkia \\
\hline Opettajien mahdollisuus vastustaa muutosta & vähäiset & runsaat \\
\hline $\begin{array}{l}\text { Opettajien toimijuuden harjoittamiseen } \\
\text { tarjotut tilat }\end{array}$ & vähäiset & laajat \\
\hline Opettajien vaikutusmahdollisuudet & vähäiset & vaihtelevat \\
\hline \multicolumn{3}{|c|}{ AMMATILLINEN LÄHIYHTEISÖTASO } \\
\hline Lähiyhteisöjen vaikutusmahdollisuudet & vähäiset & laajat \\
\hline Yhteistyö lähiyhteisöissä & vaihteleva & vaihteleva \\
\hline Yhteistyö lähiyhteisöjen välillä & vaihteleva & vähäinen /kilpailullinen \\
\hline Yhteistyöverkostot organisaation ulkopuolella & laajat & laajat \\
\hline \multicolumn{3}{|c|}{ YKSILÖTASO } \\
\hline Opettajien toimijuus opetustyössä & laaja/vaihteleva & laaja \\
\hline
\end{tabular}


myötä he muun muassa työskentelevät yhä enemmän yhteistyössä oppilaitoksen ulkopuolisten työelämän edustajien kanssa, osallistuvat opiskelijoiden työssäoppimisen suunnitteluun, organisointiin ja arviointiin, informoivat koulun ulkopuolisia tahoja koulutusta koskevista uudistuksista ja markkinoivat koulutusta työelämässä. Lisäksi opettajat tuntevat olevansa velvoitettuja hoitamaan kasvavassa määrin kehittämistehtäviä ja hallinnollisia töitä.

Opettajat kuvasivat koulutusorganisaatiotaan hierarkkiseksi ja byrokraattiseksi. He kertoivat, että heidän työtään säädellään ja kontrolloidaan yhä voimakkaammin organisaation rakenteellisen ja hallinnollisen uudistamisen jälkeen. He eivät koe pystyvänsä vaikuttamaan työtään koskeviin muutoksiin eivätkä tunne vahvaa toimijuutta ajankohtaisessa uudistustilanteessa, jossa lisätään koulutuksen työelämälähtöisyyttä ja opiskelijoiden työssäoppimista. Opettajat kertoivat olevansa voimattomia vaikuttamaan tähän opetussuunnitelmauudistukseen, sillä hallinto suunnittelee ja organisoi sitä voimakkaasti. Tästäkin huolimatta hallinto ja esimiehet edellyttävät opettajien olevan joustavia ja suorittavan heille määritellyt työtehtävät uudistustilanteessa. Opettajien mukaan hallinto ei ole myöskään tiedottanut riittävästi meneillään olevasta opetussuunnitelmauudistuksesta tai yleensä uudistuksista eikä perustellut, miksi koulutuksen ja opettajan työn sisällöt muuttuvat jatkuvasti. Opettajat ajattelevat olevansa sitoutuneempia organisaation linjauksiin, jos organisaatio perustelisi uudistuksia paremmin.

Opettajat kertoivat, että yleensäkin organisaation keskushallinto tekee usein tärkeät päätökset opettajan työstä sekä koulutuksen sisällöistä, toteutuksesta ja resursseista kysymättä opettajien mielipiteitä. Vuoropuhelua opettajien ja hallinnon välillä ei juuri esiinny. Opettajat eivät koe omaavansa paljoa päätösvaltaa ja vaikutusmahdollisuuksia monissa työnsä keskeisissä kysymyksissä. Heidän kuitenkin oletetaan hyväksyvän organisaation määrittämät tavoitteet ja toteuttavan hallinnosta tulevia määräyksiä. Eräs opettaja kertoi:
Olen vähä ymmälläni, sanotaan näin, että minä koen, että vähän on semmoista merkkiä, että yksittäistä opettajaa ei kuultaisi enää niin paljo kuin aikaisemmin, että käsky käskynä ja se tulee sen kummemmin perustelematta käytäntöön.

Tällainen johtamistapa nähdään merkkinä siitä, ettei opettajia arvosteta. Opettajat ovat tyytymättömiä vähäisiin mahdollisuuksiinsa tehdä päätöksiä, ja he haluavat lisää vaikutusmahdollisuuksia organisaatiossa ja keskustelumahdollisuuksia hallinnon edustajien kanssa.

Ammatillinen lähiyhteisötaso. Opettajat kokevat, etteivät voi vaikuttaa laajasti organisaation päätöksiin myöskään ryhmänä. Ammatillisissa lähiyhteisöissä opettajat kertoivat kuitenkin voivansa neuvotella melko hyvin konkreettisista opetukseen ja sen toteutukseen liittyvistä kysymyksistä. Yhteistyö lähiyhteisössä vaihtelee, mutta yleisesti opettajat kokevat, että yhteistyötä ei ole riittävästi. Syynä tähän on esimerkiksi kiire ja opettajien erilaiset aikataulut. Näin ollen organisaation ei katsota tarjoavan ihanteellista ympäristöä opettajien yhteistyölle eikä lähiyhteisöjen koeta luovan kaikille opettajille mahdollisuuksia ammatilliseen kiinnittymiseen. Lisäksi yhteistyön puute sekä riittämätön palaute luovat esteitä opettajien oppimiselle. Monet opettajat haluaisivat lisää yhteistyötä ryhmissä.

Ammatillisten lähiyhteisöjen keskinäiset suhteet koettiin vaihteleviksi. Organisaation rakenteellisten ja hallinnollisten rajojen kuvattiin toimivan opettajien yhteistyötä vastaan. Toisaalta opettajat, jotka olivat osallistuneet kehittämisprojekteihin, kertoivat mahdollisuuksista tehdä yhteistyötä muiden aineiden opettajien kanssa. Opettajien verkostot organisaation ulkopuolisten yhteistyökumppanien ja viiteryhmien kanssa ovat vastaavasti laajat erityisesti työelämän edustajien kanssa. Monet opettajat ajattelevat myös, että heillä on paremmat mahdollisuudet keskustella ammatillisista asioista ja kehittyä ammatillisesti organisaation ulkopuolella kuin organisaation sisällä.

Yksilötaso. Tiukkakytkentäisessä organisaatiossa opettajilla vaikuttaa olevan toimijuuden tunnetta 
silloin, kun he opettavat ja ohjaavat oppilaita. Enimmäkseen he kertoivat, että heidän työtään ei tällöin valvota eikä ohjeisteta hallinnollisesti kovinkaan yksityiskohtaisesti. Erään opettajan sanoin "minun työhöni ei ole koskaan kajottu, eli tietysti pitäisi ajatella, että se on melkoinen luottamussysteemi". Jotkut opettajat kuitenkin korostivat, että organisaatiolla on tietyt rajat opettajan toiminnalle ja opetustyölle. Organisaatio kontrolloi ja puuttuu opettajien toimintaan, jos he eivät toimi oppilaitoksen hyväksymien toimintatapojen mukaisesti.

\section{Väljäkytkentäisen organisaation hallinnollinen säätely}

Työorganisaatiotaso. Myös tämän koulutusorganisaation opettajat kertoivat, että valtakunnalliset ja paikalliset uudistukset ovat vaikuttaneet heidän työhönsä. Uudistuksista huolimatta opettajat kuvailivat, että heidän tärkeiksi kokemansa työn sisällöt eivät ole uhattuina ja että he pystyvät vaikuttamaan työhönsä ja siihen liittyviin muutoksiin. He kertoivat, että heillä oli mahdollisuuksia neuvotella hallinnon määräyksistä ja vastustaa niitä, jos he kokivat niiden uhkaavan työtään.

Neuvottelumahdollisuus ulottuu myös yhteisiin asioihin liittyvään päätöksentekoon. Jotta opettaja pystyy vaikuttamaan yhteisiin asioihin, hänen on kuitenkin tunnettava organisaation käytänteet ja toimintatavat. Yhteisiin asioihin ja päätöksentekoon vaikuttaminen edellyttää aktiivisuutta, mikä ilmaistiin usein osallistumisena erilaisiin työ- ja suunnitteluryhmiin tai vaikuttamisena ja yhteydenottona suoraan organisaation avainhenkilöihin. Tämä tulee esiin esimerkiksi opetussuunnitelmauudistuksen yhteydessä. Opettajat kuvasivat opetussuunnitelmauudistuksen pikemmin organisaation sisällä tapahtuvana ja opettajien keskinäisen neuvottelun kautta syntyvänä prosessina kuin hallinnollisten päätösten toimeenpanona. Yleisesti opettajat kokevat vahvaa toimijuutta eivätkä he ilmaisseet olevansa hallinnollisten rakenteiden kahlehtimia. Eräs opettaja totesi asian näin:

Tän talon ehdottomasti paras puoli on se, että saa siihen omaan työhönsä vaikuttaa niin paljon kun siihen voi vaikuttaa. Musta olisi kauhistus noudattaa toisten antamia käskyjä.
Opettajat kertoivat, että heillä on mahdollisuus vastustaa jopa keskushallinnosta tulevia ohjeistuksia, mikäli he katsovat näiden uhkaavan työnsä toteuttamista. Erilaisina vastustamisen tapoina kuvattiin esimerkiksi hallinnollisten ohjeiden jättäminen huomiotta tai määräysten toteuttaminen mahdollisimman pienellä työmäärällä.

Organisaatiossa toteutettu palkkauudistus oli kuitenkin poikkeus opettajien mahdollisuuksissa neuvotella hallinnon ohjeistuksista ja vastustaa niitä. Monet opettajat toivat esiin huolen keskushallinnon kasvavasta roolista palkkaneuvotteluissa. Opettajat kertoivat, että palkkauudistus loi epävarmuutta, koska he eivät tienneet, miten palkkauudistus vaikuttaisi työn ehtoihin, eivätkä he tienneet sitä, miten uudessa tilanteessa olisi järkevintä neuvotella oman palkkakehityksen turvaamiseksi. Huolen lisäksi palkkauudistus ja sen mukanaan tuomat käytänteet koettiin myös nöyryyttävinä ja omaa asiantuntijuutta loukkaavina.

Ammatillinen lähiyhteisötaso. Opettajien lähiyhteisö näyttäytyy merkittävimpänä viiteryhmänä useimmille opettajille. Lähiyhteisö tarjoaa mahdollisuuden ammatilliselle samaistumiselle ja tuottaa resursseja identiteettineuvottelulle. Opettajat kertoivat oman yhteisönsä tarjoavan mahdollisuuksia keskustella työstä ja kehittää sitä. Eri yhteisöjen asema näyttäytyy myös hyvin itsenäisenä, eikä niiden toimintaa juurikaan ohjailla hallinnollisilla ohjeistuksilla.

Vaikka ammatillisissa lähiyhteisöissä neuvotellaan ja tehdään tiivistä yhteistyötä, eri lähiyhteisöjen välinen yhteistyö on harvinaista. Opettajat kertoivat, että yhteistyötä on pyritty kehittämään monin eri keinoin ja kehittämishankkein, mutta yritykset eivät ole johtaneet pysyviin muutoksiin organisaation sisällä. Ryhmien välisen yhteistyön kuvattiinkin hauraaksi ja toimivan yksittäisten opettajien aktiivisuuden varassa.

Yhteistyö ja verkostoituminen eri viiteryhmien kanssa ja organisaation ulkopuolella on kuitenkin yleistä. Opettajat kuvailivat verkostoitumisen muiden kasvatus- ja koulutusalan asiantuntijoiden kanssa luonnolliseksi osaksi omaa työtään ja myös organisaation johto motivoi heitä tekemään yh- 
teistyötä organisaation ulkopuolisten toimijoiden kanssa.

Yksilötaso. Väljäkytkentäisessä organisaatiossa opettajat kokevat vahvaa toimijuutta työssään. He kertoivat pystyvänsä työskentelemään itsenäisesti sekä kehittämään työtään, kuten haluavat. He kuvasivat, että hallinto ei rajoittanut heidän työtään, mitä eräs opettaja kuvaili:

Jokainen hoitaa oman opetuksensa ja sitten meiltä valmistuu opettajia. Se on se meidän linja, että jokainen hoitaa omat juttunsa... ja kun jokainen saa hoitaa omat hommansa, niin siinä voi tehdä ihan mitä lystää.

Sen lisäksi, että työtä kuvaillaan hyvin itsenäiseksi, se koetaan usein myös irrallisena muiden opettajien työstä.

\section{AMMATILLISET ORIENTAATIOT JA SUHDE HALLINNOLLISEEN SÄÄTELYYN}

Seuraavaksi kuvaamme opettajien ammatillisia orientaatioita sekä sitä, miten näiden orientaatioiden harjoittaminen on mahdollista eri koulutusorganisaatioissa. Opettajien orientaation ja koulutusorganisaation hallinnollisen säätelyn välistä suhdetta käsittelemme sitoutumisen näkökulmasta.

\section{Opettajien ammatilliset orientaatiot}

Tunnistimme opettajien haastatteluista neljä ammatillista orientaatiota: (a) kasvatusorientaation, (b) oppiaineorientaation, (c) yhteistyöorientaation sekä (d) tutkimus- ja kehittämisorientaation. Orientaatioita ei tule ymmärtää muuttumattomiksi eikä toisistaan erillisiksi vaan dynaamisiksi, päällekkäisiksi ja neuvoteltaviksi. Jokaiselta opettajalta voitiin kuitenkin tunnistaa yksi muita vahvempi orientaatio.

Kasvatukseen orientoituneet opettajat pitivät tärkeimpänä tehtävänään opiskelijoiden kasvattamista ja näiden persoonallisen kehittymisen tukemista. Heille oppiaineen opettaminen ei ole tärkein tehtävä, vaan he haluavat keskittyä opiskelijan kokonaisvaltaiseen kehittymiseen ja hyvinvointiin. He välittävät opiskelijoistaan, haluavat auttaa näitä näiden ongelmissa, parantaa näiden itsetuntoa sekä estää näitä syr- jäytymästä. He korostivat elämänarvojen opettamisen tärkeyttä. Oppiaineorientoituneet opettajat taas kertoivat, että heille tärkeintä ja merkityksellisintä työssä on opetettava aine; he haluavat opettaa ainettaan ja auttaa opiskelijaa saavuttamaan pätevyyden oppiaineessa. Koulukontekstissa he pyrkivät edistämään opiskelijan ammatillisen identiteetin rakentumista sekä asiantuntijuuden ja ammatillisen osaamisen kehittymistä. Lisäksi he pitävät tärkeänä, että opiskelijat tietävät, miten kehittää ammatillisia tietoja ja taitoja valmistumisen jälkeen. He sanoivat, että opettajan velvollisuus on antaa realistinen kuva ammatista ja erilaisista työpaikoista.

Kun kasvatus- ja oppiaineorientoituneet opettajat keskittyvät pääasiassa kasvattamiseen ja opettamiseen koulutusinstituutiossa, yhteistyöorientoituneet opettajat suuntautuvat työhönsä laajemmin. He haluavat toimia koulutusorganisaation ulkopuolella yhteistyössä eri toimijoiden ja tahojen kanssa, kuten työelämän edustajien ja muiden koulutusinstituutioiden. Vastaavasti tutkimus- ja kehittämisorientoituneet opettajat pitivät tärkeimpinä tehtävinään tutkimusta, koulutuksen kehittämistä ja osallistumista kehittämisprojekteihin. Lisäksi heidän tavoitteenaan on tuottaa tietoa omasta oppiaineesta valtakunnallisesti.

\section{Ammatilliset orientaatiot tiukkakytkentäisessä organisaatiossa}

Organisaation vahva hallinnollinen säätely toisaalta rajoittaa opettajien tiettyjä ammatillisia orientaatioita ja toisaalta mahdollistaa toisten ammatillisten orientaatioiden harjoittamisen. Kasvatus- ja oppiaineorientoituneet opettajat kokivat, että he eivät pysty vapaasti toimimaan haluamissaan tehtävissä, koska organisaation vaatimukset ja työtä koskevat määritykset ovat ristiriitaisia heidän orientaatioidensa kanssa. Tämän takia opettajien ammatillinen identiteetti on uhattuna ja opettajat ovat melko tyytymättömiä työhönsä. Kaikki kasvatus- ja oppiaineorientoituneet opettajat eivät tunne olevansa vahvasti sitoutuneita organisaatioon. Lisäksi he korostavat sitoutumisen heikkenevän entisestään, jos työnkuva muuttuisi eikä siinä painottuisi edes nykyisessä määrin kasvatus- ja opetustehtävät: 
Opettajan työnkuvaan tulee muutoksia, muun työn osuus lisä̈ntyy ja opettajalta vaaditaan enemmän tällaisia organisointi- ja suunnittelutaitoja. Se on pieni huolenaihe. En ole tyypiltäni mikään organisoija ja oikeastaan suunnittelijakaan. Olen enemmän tekijä. Se voi jossain vaiheessa käydä liian raskaaksi. Jos koen, että olen enemmän suunnittelija ja kehittäjä kuin opettaja, siinä vaiheessa varmaan mietin jotain muuta työtä.

Osa kasvatus- ja oppiaineorientoituneista opettajista ei kuitenkaan halua lähteä organisaatiosta, tai ei näe muita vaihtoehtoja kuin sitoutua organisaatioon. He eivät esimerkiksi koe omaavansa riittävää ammatillista osaamista siirtyäkseen toiseen ammattiin.

Sen sijaan yhteistyöorientoituneet sekä tutkimus- ja kehittämisorientoituneet opettajat pystyvät paremmin toteuttamaan ammatillisia orientaatioitaan tiukkakytkentäisessä organisaatiossa kuin kasvatus- ja oppiaineorientoituneet opettajat. Jos opettajat kokevat mahdolliseksi harjoittaa ammatillista orientaatiotaan, heillä näyttää olevan positiivinen asenne työhön. Vaikka työn sisältöjä koskevat määritykset mahdollistavat mielekkäiden kehittämis- ja yhteistyötehtävien suorittamisen, resurssien puutteen nähdään osittain hankaloittavan työn tekemistä halutulla tavalla.

Tiukkakytkentäisessä organisaatiossa opettajien asenteet koulutuksellisiin muutoksiin vaihtelevat pääosin opettajien ammatillisista orientaatioista johtuen. Esimerkiksi jotkut opettajat suhtautuivat myönteisesti haastattelujenaikaiseen opetussuunnitelmauudistukseen, joka lisäsi koulutuksen työelämälähtöisyyttä ja opiskelijoiden työssäoppimista. Toisaalta jotkut opettajat kokivat, että uudistus oli tarpeeton ja sillä oli kielteisiä vaikutuksia erityisesti omaan työhön ja opiskelijoiden oppimiseen. (Vähäsantanen \& Eteläpelto 2009.) Jotkut opettajat kuvasivat jatkuvia muutoksia myös uuvuttaviksi sekä toivoivat työhönsä vakautta. Nämä opettajat kertoivat, että jatkuva muutos vähentää heidän sitoutumistaan organisaatioon tulevaisuudessa. (Vähäsantanen \& Billett 2008.)

\section{Ammatilliset orientaatiot väljäkytkentäisessä organisaatiossa}

Myös tässä organisaatiossa opettajat kuvasivat, että hallinnolliset tahot, kuten opetusministeriö tai organisaation keskushallinto, vaikuttavat heidän työhönsä ja käytettävissä oleviin resursseihin. Opettajat kuitenkin kertoivat, että heidän on mahdollista neuvotella työnsä sisällöistä sekä vastustaa määräyksiä ja ohjeistuksia, mikäli ne uhkaavat oman työn mielekästä toteuttamista. Hallinnolliset rakenteet ja säätely eivät näytä oleellisesti estävän ammatillisten orientaatioiden harjoittamista. Opettajat kykenevätkin toimimaan ammatillisen orientaationsa mukaisesti riippumatta siitä, millainen orientaatio heillä on. Erään opettajan sanoin:

Täällä on vapaus. Vapaus. Tarkoitan vapaudella sitä, että voin vaikuttaa omaan työhöni, minä voin vaikuttaa työyhteisössä ja jos vertaan aikaisempiin töihini niin täälä minä voin tehdä yhtä sun toista asioiden eteen.

Samoin kuin tiukkakytkentäisessä organisaatiossa, myös väljäkytkentäisessä organisaatiossa opettajat kertoivat, että hallinnollinen työ on lisääntynyt edellisinä vuosina huomattavasti. Opettajien työssä tämä näkyy erityisesti hallinnollisen suunnittelun ja kokouksien määrän kasvuna. Opettajilla on kuitenkin mahdollisuuksia neuvotella työnsä sisällöistä, ja lisäksi monet opettajat haluavat osallistua organisaation erilaisiin työ- ja suunnitteluryhmiin. Opettajat kertoivat, että osallistumalla heillä on mahdollisuus tehdä ehdotuksia sekä vaikuttaa keskeisiin ja heille merkityksellisiin asioihin. Organisaatio tarjoaa monia mahdollisuuksia tällaiseen neuvotteluun. Opettajat ovat erittäin sitoutuneita työhönsä ja halukkaita kehittämään sitä. Lisäksi he kertoivat haluavansa jatkaa työskentelyä organisaatiossa myös tulevaisuudessa:

Minulla on selkeä visio siitä, että haluaisin olla laitoksessa ja kehittyä täällä ja omalta osaltani [vaikuttaa] myöskin tämän laitoksen kehittymiseen ... kyllä aion olla ja kehittyä ja musta on hyvä, että voi ite vaikuttaa ja jopa rytmittää sitä kehittymisen tahtia. 
Yleisesti opettajat eivät suhtaudu epäluuloisesti muutoksiin tai organisaation kehittämiseen. Päinvastoin jotkut opettajat pitivät muutoksia toivottavina. Organisaation kehittämisessä ja muutosten toteuttamisessa tavoiteltavana nähdään kuitenkin se, että opettajat itse toimisivat muutosten veturina sen sijaan, että muutokset tulisivat jonkin ulkopuolisen tai hallinnollisen tahon aloitteesta.

\section{POHDINTA}

Tulokset osoittavat, että tiukkakytkentäinen organisaatio (ammatillinen oppilaitos) rajoittaa opettajien toimijuutta ja toimimista ammatillisten orientaatioiden mukaisesti enemmän kuin väljäkytkentäinen organisaatio (yliopiston opettajankoulutuslaitos). Tiukkakytkentäinen organisaatio luo myös jatkuvia muutosodotuksia. Sitä vastoin väljäkytkentäisessä organisaatiossa opettajat pystyvät neuvottelemaan työnsä sisällöistä ja toimimaan oman orientaationsa mukaan. Toisin sanoen väljäkytkentäisessä organisaatiossa opettajilla on mahdollisuus harjoittaa toimijuutta.

Tulokset osoittavat myös, että opettajat ovat sitoutuneempia koulutusorganisaatioon, jos heillä on riittävästi toimijuutta ja mahdollisuuksia harjoittaa omaa ammatillista orientaatiotaan ja jos heidän toimintaympäristönsä on suhteellisen vakaa (vrt. Day ym. 2005; Little \& Bartlett 2002).

Suomalaista työelämää koskevassa tutkimuksessa on myös osoitettu, että asiantuntijatyön johtaminen käskyttämällä ja ulkoisen kontrollin lisääminen näyttävät heikentävän työntekijöiden sitoutumista ja työn mielekkääksi kokemista. Huolenaiheena nähdään myös, että työntekijät eivät pysty käyttämään riittävästi osaamistaan ja luovuuttaan, jos heidän vaikutusmahdollisuuksiaan työhönsä rajoitetaan. (ks. Eteläpelto, Heiskanen \& Collin 2011.) Näyttääkin siltä, että koulutus- ja työorganisaatioiden johtamisessa tulisi tukea yksilöiden toimijuutta ja mahdollistaa yksilöiden ammatillisten intressien toteuttaminen, jotta he voisivat sitoutua työhönsä ja organisaatioonsa.

Viimeaikaiset työorganisaatioiden muutokset ovat vaikuttaneet perinteisten työidentiteettien rakentumiseen, koska muutokset ovat heikentäneet mahdollisuuksia kuulua ja samaistua tiettyyn työyhteisöön (Kirpal 2004). Myös monet haastatelluista opettajista haluaisivat tehdä enemmän yhteistyötä ammatillisissa lähiyhteisöissä. Vaikka opettajille on tärkeää vahva toimijuuden tunto ja yksilöllisten ammatillisten orientaatioiden toteuttaminen, tutkimuksemme tuloksissa korostuu ammatillisen lähiyhteisön merkitys. Opettajien lähiyhteisö ja sen mahdollistama yhteistyö luovat esimerkiksi turvaa ulkopuolisia muutoksia vastaan. Tuloksista voi päätellä, että keskeistä opettajien onnistuneille ammatillisille identiteettineuvotteluille ovat riittävä toimijuus sekä mahdollisuus kuulua kannustavaan ja turvalliseen ammatilliseen lähiyhteisöön.

Vaikka väljäkytkentäinen organisaatio tuki opettajien sitoutumista erityisesti luomalla tilaa opettajien toimijuudelle ja erilaisten ammatillisten orientaatioiden toteuttamiselle, tällainen organisaatio ei välttämättä ole ihanteellinen opettajien yhteisöllisen oppimisen ja organisaation kehittymisen kannalta. Väljäkytkentäisessä organisaatiossa ongelmaksi koetaan se, että ammatilliset ryhmät eivät jaa kokemuksia eivätkä tietoa keskenään, sillä ryhmien väliset suhteet ovat heikkoja. Lisäksi opettajien vahva toimijuus ja itsenäiset ammattiryhmät näyttävät estävän organisaation ja koulutuksen uudistusten toteutumista. Tulokset tukevat siten näkemyksiä siitä, että organisaation kehittyminen ja oppiminen voi estyä, jos yksilöt kehittävät pelkästään omaa asiantuntijuuttaan eikä tieto siirry organisaation sisällä (Hökkä, RaskuPuttonen \& Eteläpelto 2008; Nonaka \& Takeuchi 1995). Sitä vastoin tiukkakytkentäinen organisaatio tuottaa vahvan hallinnollisen säätelyn kautta jatkuvasti organisaation ja koulutuksen uudistuksia.

Vaikka vahva hallinnointi näytti edesauttavan uudistusten toteutusta, organisaatiossa kaivattaan enemmän vuoropuhelua opettajien ja hallintohenkilöstön välille, sillä näin opettajien kokemuksia ja tietoja olisi mahdollista hyödyntää uudistusprosesseissa ja tukea samalla opettajien sitoutumista uudistuksiin.

Tuloksemme osoittavat, että koulutusorganisaatioiden väljä- ja tiukkakytkentäisyydellä on omat heikkoutensa ja vahvuutensa. Koulutusorganisaatioiden hallintoa ei tulisikaan yksiselitteisesti kehittää kohti vahvaa ja tiukkaa hallinnollista säätelyä, mikä näyt- 
tää olevan vallitseva suuntaus. Sen sijaan tarvittaisiin uudenlaisia hallinnon tapoja, jotka tukevat opettajien sosiaalista vuorovaikutusta sekä opettajien ja organisaatioiden hallinnon välistä yhteistyötä mutta jättävät samalla tilaa yksilöiden ammatilliselle toimijuudelle (Hökkä, Vähäsantanen \& Saarinen 2010).

Toimijuuden mahdollistaminen merkitsee opettajien vaikutusmahdollisuuksien lisäämistä ja opettajien valtauttamista aktiivisiksi toimijoiksi. Tämä tarkoittaa opettajien mahdollisuutta harjoittaa omaa ammatillista orientaatiotaan, neuvotella aktiivisesti työnsä ehdoista ja sisällöistä sekä vaikuttaa työyhteisönsä ja organisaationsa asioihin. Vahvalle toimijuudelle ja sitoutumiselle ei olekaan riittävää, että opettajat voivat harjoittaa toimijuutta ainoastaan omassa

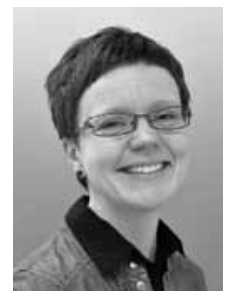

Katja Vähäsantanen

tutkija, kasvatustieteiden laitos Jyväskylän yliopisto

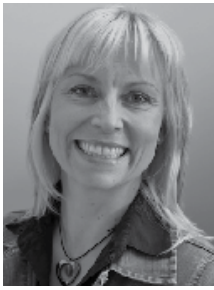

Päivi Hökkä

tutkija, kasvatustieteiden laitos Jyväskylän yliopisto opetustyössään, vaan lisäksi on oltava mahdollisuus osallistua yhteisö- ja organisaatiotason päätöksentekoon. Siksi on tärkeää, että keskustelussa toimijuudesta otetaan huomioon niin organisaation taso, lähiyhteisön taso kuin yksilönkin taso.

\section{KIITOKSET}

Tutkimus on saanut tukea Suomen Akatemian tutkimusprojekteista no. 139538. Artikkeli pohjautuu alkuperäisartikkeliin Vähäsantanen, K., Hökkä, P., Eteläpelto, A., Rasku-Puttonen, H. \& Littleton, K. (2008). Teachers' professional identity negotiations in two different work organisations. Vocations and Learning: Studies in Vocational and Professional Education, 1(2), 131-148.

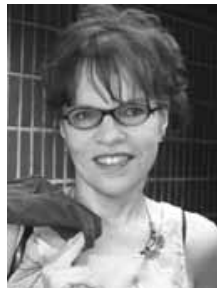

Anneli Eteläpelto

professori, kasvatustieteiden laitos

Jyväskylän yliopisto

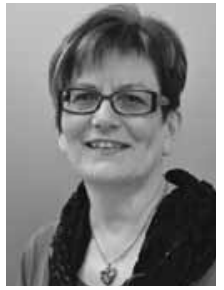

Helena Rasku-Puttonen

professori, opettajankoulutuslaitos Jyväskylän yliopisto

\section{LÄHTEET}

Baruch, Y. \& Cohen, A. (2007). The dynamics between organisational commitment and professional identity formation at work. Teoksessa Brown, A., Kirpal, S. \& Rauner, F. (toim.) Identities at work. Dordrecht: Springer, 241-260.

Beijaard, D., Meijer, P.C. \& Verloop, N. (2004). Reconsidering research on teachers' professional identity. Teaching and Teacher Education 20(2), 107-128.

Billett, S. (2007). Exercising self through working life:
Learning, work and identity. Teoksessa Brown, A., Kirpal, S. \& Rauner, F. (toim.) Identities at work. Dordrecht: Springer, 183-210.

Braun, V. \& Clarke, V. (2006). Using thematic analysis in psychology. Qualitative Research in Psychology 3(2), 77-101.

Day, C., Elliot, B. \& Kington, A. (2005). Reform, standards and teacher identity: Challenges of sustaining commitment. Teaching and Teacher Education 21(5), 563-577. 
Eteläpelto, A. (2008). Perspectives, prospects and progress in work-related learning. Teoksessa Billett, S., Harteis, C. \& Eteläpelto, A. (toim.) Emerging perspectives of workplace learning. Rotterdam: Sense, 233-247.

Eteläpelto, A. \& Saarinen, J. (2006). Developing subjective identities through collective participation. Teoksessa Billett, S., Fenwick, T. \& Somerville, M. (toim.) Work, subjectivity and learning: Understanding learning through working life. Dordrecht: Springer, 157-177.

Eteläpelto, A. Heiskanen. T. \& Collin, K. (2011). Mahdollisuudet, tilat ja toisin tekemisen paikat työssä ja koulutuksessa. Teoksessa Eteläpelto, A. Heiskanen. T. \& Collin, K. (toim.) Valta ja toimijuus aikuiskasvatuksessa. Aikuiskasvatuksen 49. vuosikirja. Helsinki: Kansanvalistusseura, 355-365.

Fenwick, T. (2006). Escaping/becoming subjects: Learning to work the boundaries in a boundaryless work. Teoksessa Billett, S., Fenwick, T. \& Somerville, M. (toim.) Work, subjectivity and learning: Understanding learning through working life. Dordrecht: Springer, 21-36.

Hargreaves, A. (2000). Four ages of professionalism and professional learning. Teachers and Teaching: Theory and Practice 6(2), 151-182.

Helgøy, I., Homme, A. \& Gewirtz, S. (2007). Local autonomy or state control? Exploring the effects of new forms of regulation in education. European Educational Research Journal 6(3), 198-202.

van Huizen, P., van Oers, B. \& Wubbels, T. (2005). A Vygotskian perspective on teacher education. Journal of Curriculum Studies 37(3), 267-290.

Hökkä, P., Rasku-Puttonen, H. \& Eteläpelto, A. (2008). Teacher educators' workplace learning: The interdependency between individual agency and social context. Teoksessa Billett, S., Harteis, C. \& Eteläpelto, A. (toim.) Emerging perspectives of workplace learning. Rotterdam: Sense, 51-65.

Hökkä, P., Vähäsantanen, K. \& Saarinen, J. (2010). Toimijuuden tilat ja tunnot - Opettajien muuttuva työ koulutusorganisaatiossa. Teoksessa Collin, K., Paloniemi, S., Rasku-Puttonen, H. \& Tynjälä, P. (toim.) Luovuus, oppiminen ja asiantuntijuus Koulutuksen ja työelämän näkökulmia. Helsinki: WSOY, 141-159.

Kirpal, S. (2004). Researching work identities in a European context. Career Development International 9(3), 199-221.

Lasky, S. (2005). A sociocultural approach to understanding teacher identity, agency and professional vulnerability in a context of secondary school reform. Teaching and Teacher Education 21(8), 899-916.
Little, J.W. \& Bartlett, L. (2002). Career and commitment in the context of comprehensive school reform. Teachers and Teaching: Theory and Practice 8(3), 345-354.

Meyer, H-D. (2002). From "loose coupling" to "tight management"? Making sense of the changing landscape in management and organization theory. Journal of Educational Administration 40(6), 515-520.

Meyer, J.W. \& Rowan, B. (1977). Institutionalized organizations: Formal structure as myth and ceremony. American Journal of Sociology 83(2), 340-346.

Moos, L. (2005). How do schools bridge the gap between external demands for accountability and the need for internal trust? Journal of Educational Change 614), 307-328.

Nonaka, I. \& Takeuchi, H. (1995). The knowledgecreating company: How Japanese companies create the dynamics of innovation. New York: Oxford University Press.

Patton, M.Q. (2002). Qualitative research \& evaluation methods (3. painos). Thousand Oaks: Sage.

Rinne, R. (2003). Uusliberaali ajattelutapa on pesiytynyt suomalaiseenkin koulutuspolitiikkaan. Aikuiskasvatus 23(2), 152-157.

Vanhalakka-Ruoho, M. (2006). Professionaalisuus omissa vai muiden käsissä. Teoksessa Eteläpelto, A. \& Onnismaa, J. (toim.) Ammatillisuus ja ammatillinen kasvu. Aikuiskasvatuksen 46. vuosikirja. Helsinki: Kansanvalistusseura, 124-143.

van Veen, K., Sleegers, P., Bergen, T. \& Klaassen, C. (2001). Professional orientations of secondary school teachers towards their work. Teaching and Teacher Education 17(2), 175-194.

Weick, K.E. (1976). Educational organizations as loosely coupled systems. Administrative Science Quarterly, 21(1), 1-19.

Weick, K.E. (2001). Making sense of the organization. Malden: Blackwell Publishing.

Vähäsantanen, K. \& Billett, S. (2008). Negotiating professional identity: Vocational teachers' personal strategies in a reform context. Teoksessa Billett, S., Harteis, C. \& Eteläpelto, A. (toim.) Emerging perspectives of workplace learning. Rotterdam: Sense, 35-49.

Vähäsantanen, K. \& Eteläpelto, A. (2009). Vocational teachers in the face of a major educational reform: Individual ways of negotiating professional identities. Journal of Education and Work 22(1), 15-33.

Artikkeli saapui toimitukseen 4.8.2011. Se hyväksyttiin julkaistavaksi toimituskunnan kokouksessa 26.3.2012. 